\title{
O kinie w Radiu Watykańskim - analiza treści audycji radiowych pt. „Kino - wehikuł ludzkich tęsknot”
}

\section{Cinema in Vatican Radio - analysis of the content of radio broadcasts "Cinema - the vehicle of human longings"}

\begin{abstract}
ABSTRAKT
Cykl audycji radiowych pt. „Kino - wehikuł ludzkich tęsknot” jest częścią programu Polskiej Sekcji Radia Watykańskiego. Każdy odcinek odnosi się do wybranego filmu, pochodzącego z danego przedziału czasowego $\mathrm{w}$ dziejach kina światowego. W zeszłym roku audycje zostały zdigitalizowane (w ramach projektu z MEN) i umieszczone w wolnym dostępie na platformie Polskiej Biblioteki Cyfrowej. Niniejszy artykuł sprowadza się do zwięzłej, aczkolwiek skrupulatnej analizy treści jedenastu rubryk składających się na poszczególne odcinki. Charakterystyka materiału sprowadza się do opisu zawartości słuchowisk, instytucji i osób bezpośrednio związanych z ich emisją, jak i jednostek pośrednich - projektu cyfryzacji cyklu o kinie przez PBC.

SŁOWA KLUCZOWE audycja, radio, kino, przekaz, media, Radio Watykańskie, Polska Biblioteka Cyfrowa
\end{abstract}

\begin{abstract}
A series of radio broadcasts entitled "Cinema - the vehicle of human longings" is part of the program of the Polish Section of Vatican Radio. Each episode relates to a selected film from a given time period in the history of world Cinema. The broadcasts were digitized last year (as part of a project with the Ministry of Education and Science) and placed in free access on the platform of the Polish Digital Library. Present article comes down to a concise but precise analysis of the eleven columns content, which involves the individual sections. The characteristics of the material come down to the description of the content of radio plays, institutions and people directly related to their broadcast, as well as intermediate units - project of digitization the series about Cinema by the PDL.
\end{abstract}

\section{KEYWORDS}

broadcast, radio, cinema, transmission, media, Vatican Radio, Polish Digital Library

\section{WSTĘP}

„Kino - wehikuł ludzkich tęsknot”, to cykl audycji przygotowanych przez ojca misjonarza - werbistę Andrzeja Danilewicza dla Radia Watykańskiego. Artykuł przedstawia wnikliwy opis zebranych materiałów audio pochodzących z owego 
cyklu, które zostały zdigitalizowane, a następnie udostępnione na platformie Polonijnej Biblioteki Cyfrowej ${ }^{1}$.

Publikacja ma charakter deskryptywny opierający się na analizie treści audycji radiowych. Schemat artykułu składa się z trzech głównych punktów. Po pierwsze, prezentacja osób i organizacji, które przyczyniły się do powstania, jak i później digitalizacji całego cyklu (materiałów audio) Polskiej Sekcji Radia Watykańskiego pt. „Kino - wehikuł ludzkich tęsknot”. Z tego też względu, zaprezentowana zostanie sylwetka autora audycji - ojca Danilewicza - krótka charakterystyka jego osoby posłuży w końcowej części publikacji do podjęcia tematu i udowodnienia m.in.: co łączy misjonarza, osobę duchowną z kulturą, a w szczególności z X Muzą. Czy obrana przez realizatora projektu tematyka, łączy się z jego doświadczeniem bądź kwalifikacjami? Czy pozostaje w obszarze jego zainteresowań, czy może daleko poza nie wykracza? Ponadto zwięzłe zaprezentowanie instytucji Misjonarzy Werbistów - historii i bogatej działalności, obejmującej także komunikację medialną, która łączy się z osobą o. Danilewicza. Co więcej, w podanej publikacji przybliżone zostaną zwięzłe opisy: projektu Polonijnej Biblioteki Cyfrowej - miejsca otwartego dostępu do plików audio polskiej sekcji radia watykańskiego, jak również wspomnianej organizacji Radia Watykańskiego - macierzystego medium dla audycji „Kino - wehikuł ludzkich tęsknot”. Punkt drugi stanowi rozprawę na temat koneksji radia z kinem. Pierwsze polskie audycje radiowe odnośnie do kina i ich rozwój. Następnie, w punkcie trzecim autorka przejdzie do głównego obiektu badań, czyli rubryk z audycjami i dokona opisu, uwzględniając w nim przedmiot główny - film. W każdym z odcinków radiowych omawiany jest jeden, wybrany film. Celem analizy audycji radiowych, jest przede wszystkim popularyzacja opublikowanych na stronie Polonijnej Biblioteki Cyfrowej materiałów, które dotąd nie stanowiły przedmiotu badań żadnej innej publikacji naukowej. Autorka poprzez swoją pracę zamierza przybliżyć, jakie tematy, a przede wszystkim jakie filmy stanowią rozprawę audycji ojca A. Danilewicza. Ostatnią część artykułu stanowią wnioski.

Celem podjętej analizy treści audycji radiowych, jest przede wszystkim wnikliwa charakterystyka zawartej w nich tematyki, tj. poznanie głównego przedmiotu treści każdego odcinka - filmu. A konkretnie: jakie obrazy filmowe zostały wybrane i omówione w cyklu audycji „Kino - wehikuł ludzkich tęsknot”? Jakie

${ }^{1}$ zob. http://www.pbc.uw.edu.pl/ 
cezury czasowe zostały wyróżnione w danej podróży filmowej? Gdyż, jak sam tytuł sugeruje - kino przyrównane jest w nim do wehikułu², a więc dane audycje radiowe są podróżą w czasie, co więcej powrotem do przeszłości - co z kolei sugerują nam słowa „ludzkich tęsknot”. Lekturą pomocniczą jak i podstawową dla części analitycznej (metodologicznej) jest publikacja Karoliny Szczepaniak pt. Zastosowanie analizy treści $w$ badaniach artykułów prasowych - refleksje metodologiczne ${ }^{3}$, wedle której w sposób systematyczny i ilościowy zostanie opisany materiał badawczy - wybrane filmy w audycjach radiowych. Autorka publikacji wysnuwa kilka kategorii badawczych dla analizy treści odcinków (punkt trzeci w publikacji), w tym rozpoznania filmów pod względem: 1.Gatunkowości, 2. Narodowości, 3. Roku produkcji (cezura czasowa), jak i 4. Reżysera.

Dzięki powyższym kryteriom zostanie sporządzona czytelna i przejrzysta lista dzieł filmowych danego cyklu audycji (zebranych i umieszczonych w jednej tabeli na końcu publikacji), jak również ich ilościowe badanie (charakterystyczne dla analizy treści) ${ }^{4}$, jak i klasyfikacja. Co więcej, dane kategorie pozwolą ukazać motywację bądź koncepcję, którą kierowali się realizatorzy audycji przy wyborze danych dzieł, składających się na całokształt cyklu o jakże zagadkowym a zarazem znaczącym tytule: „Kino - wehikuł ludzkich tęsknot”.

Przedłożona publikacja w dużej mierze odnosi się do źródeł online, m.in. witryn internetowych instytucji i zgromadzeń werbistów, polonijnej biblioteki cyfrowej, wirtualnego muzeum cyfrowego, jak również innych katolickich czy świeckich platform medialnych odwołujących się do tematu. Ze względu na główne źródło badań, tj. witrynę Polonijnej Biblioteki Cyfrowej, z której autorka publikacji czerpie materiał (audycje radiowe), spora część odsyłaczy źródłowych będzie charakteryzowała się zauważalną powtarzalnością. Należy jednak zwrócić uwagę na fakt, iż jest to temat stricte odnoszący się do nowej formy - zdigitalizowanych, scyfryzowanych ${ }^{5}$ mediów, które umieszczone w jednym miejscu, w wolnym dostępie, umożliwiają ich uporządkowaną i wnikliwą analizę.

${ }^{2}$ Według „Słownika Języka Polskiego”, termin „wehikuł” oznacza: w powieściach lub filmach fantastycznonaukowych: urządzenie przenoszące ludzi w przeszłość lub przyszłość, https://sjp.pwn.pl/slowniki/wehiku\%C5\%82.html (dostęp: 4.05.2021).

${ }^{3}$ K. Szczepaniak, Zastosowanie analizy treści w badaniach artykułów prasowych - refleksje metodologiczne , „Acta Universitatis Lodziensis. Folia Sociologica” 2012 z. 42, s. 83-112.

${ }^{4}$ Tamże, s. 86.

${ }^{5}$ Zmiana struktury z analogowej na cyfrową. 


\section{CHARAKTERYSTYKA INSTYTUCJIZGROMADZENIA SŁOWA BOŻEGO - WERBISTÓW I POSTACI O. ANDRZEJA DANILEWICZA}

Historia zgromadzenia sięga XIX w., a dokładniej 1875 roku, w którym to niemiecki kapłan Arnold Janssen założył pierwszy dom misyjny, w holenderskiej miejscowości Steyl nad rzeką Mozą. Dzięki wyjazdom członków zgromadzenia na misje (które stanowiły ich nieodłączny cel) instytucja werbistów poszerzyła swoją działalność o kolejne państwa, jak np. Japonia, USA, kraje Ameryki Południowej, Nowa Gwinea, Chiny czy kraje europejskie (w tym Polskę). Aktualnie wobec danych na 2020 rok, do zgromadzenia należy 6016 członków, zrzeszających 79 krajów świata i sześć kontynentów ${ }^{6}$. Genezę działalności polskiego zgromadzenia misyjnego szczegółowo opisuje w swoim artykule o. Janusz Brzozowski, który wskazuje, że pierwsi Polacy w Zgromadzeniu Słowa Bożego pojawili się dzięki Niższemu Seminarium Misyjnemu działającemu od 1892 roku w Domu Misyjnym św. Krzyża w Nysie. Jednakże osiedlenie się na stałe na ziemiach polskich, nastąpiło dopiero po I wojnie światowej, w miastach: Poznaniu i Bytomiu. Jednakże pierwsze w Polsce Niższe Seminarium Misyjne zostało założone w 1923 roku w Rybniku - dając początek prac dydaktyczno-wychowawczych dla kolejnych pokoleń werbistów ${ }^{7}$.

Poza działalnością dydaktyczno-wychowawczą, skupiającą się głównie przy Misyjnych Seminariach Duchownych Księży Werbistów, większość pozostałych inicjatyw Zgromadzenia Słowa Bożego odnosi się do animacji misyjnej społeczeństwa polskiego. $\mathrm{W}$ tym zakresie również do zaangażowania medialnego ojców werbistów. Do aktywności tego szczebla przynależą następujące zadania i inicjatywy: organizacja imprez oraz cyklicznych akcji o charakterze ściśle animacyjnym, w tym „Wakacji z misjami” oraz akcji „Kierowcy Misjom”; działalność duszpasterska na terenie parafii; duszpasterstwo rekolekcyjne (Górna Grupa, Laskowice, Nysa); duszpasterstwo specjalistyczne wśród mniejszości narodowych, emigrantów, narkomanów, chorych na AIDS, dzieci ulicy itp. (Białystok, Warszawa); praca naukowa na KUL, UKSW, Uniwersytecie Warmińsko-Mazurskim w Olsztynie oraz

${ }^{6}$ B.a., Życie zakonne. Serwis informacyjny Konferencji Wyższych Przełożonych Zakonów Męskich $w$ Polsce, z 8.04.2008, https://www.zyciezakonne.pl/informator/zakony-meskie/ werbisci-366/ (dostęp: 16.11.2020).

${ }^{7}$ J. Brzozowski, 75 lat Polskiej Prowincji Zgromadzenia Słowa Bożego (cz. I), „Misjonarz" 2012 nr 1, s. 24, http://www.misjonarz.pl/files/pdfy/misjonarz_1_2012.pdf (dostęp: 17.11.2020). 
Kolegium Teologicznym w Królewcu; działalność w środkach społecznego przekazu: Wydawnictwo VERBINUM, miesięcznik „Misjonarz” i drukarnia misyjna, Telewizja Niepokalanów, programy radiowe dla m.in. radia watykańskiego, itp.; działalność Apostolatu Biblijnego; działalność dydaktyczna; działalność Muzeum Misyjno-Etnograficznego (Pieniężno wraz z filiami w Białymstoku, Chludowie, Górnej Grupie, Nysie i Laskowicach) ${ }^{8}$. Działalność ojców werbistów jest wszechstronna - działają na najróżniejszych polach szczebla społecznego - w tym również medialnego, czego dowodem jest aktywność w środkach masowego przekazu: prasie, radiu i telewizji.

Osobą realizującą cykl audycji „Kino - wehikuł ludzkich tęsknot” dla Radia Watykańskiego (we współpracy z redaktorem Janem Pniewskim) jest ojciec werbista Andrzej Danilewicz, który z mediami jest ściśle związany, chociażby ze względu na odebraną edukację. Doświadczenie o. Danilewicza jest różnorodne, jednakże nie jest szczegółowo opisane w źródłach, do których dotarła autorka artykułu. Dlatego też niektóre informacje przedstawione zostały w sposób ogólny. Mianowicie po zdobyciu wykształcenia filozoficzno-teologicznego, o. Danilewicz wstąpił do misjonarzy werbistów w 1985 roku, a przyjął święcenia kapłańskie w kwietniu 1992 roku. W swojej posłudze misjonarskiej odbył misje zagraniczne, m.in. na Słowacji, czy w Irlandii, gdzie ukończył studia podyplomowe w Instytucie Kairos na kierunku „Chrześcijańskiej Komunikacji i Rozwoju”. Swoją przygodę z radiem rozpoczął po powrocie z zagranicy. Współpracował m.in. z Radiem Niepokalanów, przygotowywał cykliczne audycje dla Radia Watykańskiego, Radia Maryja i wielu innych rozgłośni diecezjalnych. Ojciec Danilewicz poza swoją posługą duchowną i misjonarską wyróżniał się swoim zaangażowaniem w prace na rzecz mediów. W 1998 roku objął stanowisko Prowincjonalnego Koordynatora do spraw Środków Społecznego Przekazu9. Do dziś jest aktywny w mediach, m.in. w zespole redakcyjnym miesięcznika pt. „Misjonarz. Miesięcznik księży werbistów”10. Co więcej jest autorem projektu „RównoleżnikM” misjonarzy werbistów, w którym prowadzi działalność dziennikarską w formie podcastów, prowadząc rozmowy z innymi werbistami na misjach, a także publikuje artykuły na bloga,

${ }^{8}$ Tamże, s. 22.

${ }^{9}$ zob. B.a., O. Danilewicz prowincjałem werbistów, https://info.wiara.pl/doc/164919.0-Danilewicz-prowincjalem-werbistow z 12.03.2007 (dostęp: 22.10.2020).

${ }^{10}$ zob. Misjonarz.pl, Redakcja, http://www.misjonarz.pl/pl/misjonarz-redakcja (dostęp: 22.10.2020). 
będącego częścią tego projektu ${ }^{11}$. Ponadto swoje zainteresowanie filmem wyraża na osobistym profilu społecznościowym „Twitter” (aktywny od 2011 roku), gdzie zamieszcza posty dotyczące polecanych filmów m.in. misyjnych ${ }^{12}$. Ojciec A. Danilewicz obecnie pełni rolę sekretarza ds. misji i rzecznika prasowego polskiej prowincji zgromadzenia werbistów.

\section{2a. Geneza i charakterystyka powstania Polskiej Sekcji Radia Watykańskiego}

Oficjalna data rozpoczęcia działalności radiowej Radia Watykańskiego przypada na 12 lutego 1931 r. Pierwsze słowa należały do współzałożyciela watykańskiej stacji radiowej - włoskiego konstruktora, Guglielma Marconi, który w uroczystość 40-lecia Encykliki Rerum Novarum, zapowiedział wystąpienie Papieża Piusa XI. W swojej długiej i bogatej historii, na czele Radia Watykańskiego stawało wielu przodowników (zazwyczaj byli to przedstawiciele zgromadzeń kościoła katolickiego). Poprowadzenie rozgłośni watykańskiej Pius XI powierzył Towarzystwu Jezusowemu, a pierwszym dyrektorem generalnym radia został jezuita Giuseppe Gianfranceshi. W pierwszych latach istnienia misja radia w Stolicy Apostolskiej ograniczała się tylko do celów komunikacyjnych, jednakże z biegiem lat i mających miejsce wydarzeń historycznych, ukształtował się także aspekt ewangelizacyjny i kulturowy.

Sekcja Polska Radia Watykańskiego miała swoją oficjalną inaugurację, kilka lat później, tj. 24 listopada 1938 roku. Szczególną rolę w początkach rozwoju polskiej sekcji odegrał jej ówczesny dyrektor ojciec Feliks Lasoń, a w radiowych transmisjach wspomagał go ksiądz Józef Młodochowski - rektor Papieskiego Instytutu Polskiego. Na ziemiach polskich, sekcja radia watykańskiego ograniczała się do wiadomości ze Stolicy Apostolskiej, a w szczególności do działań Papieża. Na początku audycje prowadzone były 2 razy w tygodniu, aczkolwiek wraz z kolejnymi latami rozwoju polskiej sekcji radia watykańskiego, częstotliwość zmieniła się do nadawania codziennych audycji. Polska sekcja Radia Watykańskiego powstała na krótko przed wybuchem drugiej wojny światowej. W tym burzliwym dla narodu okresie była jedyną rozgłośnią katolicką nadawaną na ziemiach polskich. Poza główną formą przekazywania treści informacyjnych z terenów włoskich - z siedziby Polskiej Sekcji Radia Watykańskiego w Palazzo Pio przy ulicy

${ }^{11}$ zob. https://www.rownoleznik.werbisci.pl/ (dostęp: 22.10.2020).

${ }^{12}$ zob. https://twitter.com/danilewiczsvd?lang=pl (dostęp: 22.10.2020). 
Piazza Pia 3 w Rzymie, napływały słowa ku pokrzepieniu serc, które napawały rodaków nadzieją i poczuciem zjednoczenia z polonią będącą za granicami kraju. Niemniej jednak to w szczególności okres pontyfikatu Papieża Jana Pawła II przyczynił się do zwiększenia grupy słuchaczy i w znacznej mierze wpłynął na przyszłość polskiej sekcji radia watykańskiego. Transmisje z audiencji papieża Polaka, relacje z pielgrzymek do Polski czy przekazywanie informacji odnośnie wizyt międzynarodowych - ekipa radia towarzyszyła papieżowi w każdej podróży, transmitując i relacjonując wydarzenia przez radiowy nośnik ${ }^{13}$. Aktualnie papieska rozgłośnia zatrudnia 384 osoby z 59 narodowości. Transmisje radiowe prowadzone są w 45 językach za pomocą internetu, telewizji satelitarnej oraz fal radiowych. Codziennie z Watykanu w eter trafia 65 godzin programów ${ }^{14}$.

Audycje Sekcji Polskiej Radia Watykańskiego nadawane są także w wielu rozgłośniach ogólnopolskich, np. w Polskim Radio Program Pierwszy, Radiu Maryja oraz w katolickich stacjach lokalnych, jak na przykład: Radio eM, Radio Jasna Góra, Radio Rodzina, Radio Nadzieja, Radio Głos, Radio Emaus, Katolickie Radio Podlasie, Radio Plus Warszawa, Radio Warszawa, czy Katolickie Radio Zamość. Przez 80 lat działalności, PSRW doczekała się pokaźnej listy współpracowników radia. Byli to znani przedstawiciele kościoła katolickiego a zarazem nauki, jak m.in.: ks. Janusz Boloneka, ks. Adam Boniecki, ks. Sławoj Leszek Głódź, prof. Stanisław Grygiela, ks. Marek Starowieyski, o. Andrzej Danilewicz, czy ks. Józef Tischner ${ }^{15}$.

\section{2b. Profil Polonijnej Biblioteki Cyfrowej - historia, cel, misja}

Polonijna Biblioteka Cyfrowa powstała w 2012 roku. Pomysłodawcą i kustoszem projektu jest prodziekan ds. finansowych Wydziału Dziennikarstwa Informacji i Bibliologii - prof. Dariusz Kuźmina. Platforma biblioteki została utworzona w drodze konkursu „Współpraca z Polonią i Polakami za granicą”, ogłoszonego przez Ministerstwo Spraw Zagranicznych. Finansowana jest głównie ze środków

${ }^{13}$ T. Dobrowolski, 60 lat polskiej sekcji radia watykańskiego, „Opoka” 12.02.1999 r., https://opoka.org.pl/biblioteka/T/TH/THW/60lat.html (dostęp: 9.11.2020).

${ }^{14}$ W. Nowakowska, Papieska rozgłośnia, „Niedziela” 12.2007 r., https://www.niedziela. pl/artykul/81727/nd/Papieska-rozglosnia (dostęp: 19.11.2020).

${ }^{15}$ J. Jaroszyński, Misja Polskiej Sekcji Radia Watykańskiego, „Kwartalnik Nauk o Mediach” 2016 z. 3, http://knm.uksw.edu.pl/misja-polskiej-sekcji-radia-watykanskiego/ (dostęp: 9.11.2020). 
projektów Senatu RP i projektów ministerialnych: z Ministerstwa Kultury i Dziedzictwa Narodowego, jak również z Ministerstwa Nauki i Szkolnictwa Wyższego. Polonijna Biblioteka Cyfrowa służy przede wszystkim zabezpieczeniu i udostępnianiu zbiorów organizacji czy instytucji zrzeszających polonię na całym świecie. Biblioteka prowadzi swoje prace w ośrodkach polonijnych na całym świecie, m.in. w Argentynie, Brazylii, Czechach, Francji, Meksyk, Peru, Stanach Zjednoczonych, czy w Wielkiej Brytanii. Głównym celem działalności PBC jest aktywność gromadzenia, zachowania a zarazem promowania zbiorów polonijnych $\mathrm{w}$ dostępie otwartym. PBC oferuje bowiem ogromnej wagi źródło historyczne dokumentujące losy Polaków poza krajem w XIX i XX w. Funkcjonowanie polonijnej biblioteki wyróżnia unikatowość i uniwersalność. Mianowicie, materiały gromadzone na platformie PBC nie dublują się ze zbiorami innych polonijnych instytucji tj. Polony czy Biblioteki Narodowej - natomiast są ich istotnym i brakującym uzupełnieniem ${ }^{16}$.

Kolekcja Polonijnej Biblioteki Cyfrowej została podzielona na trzy kategorie, mianowicie: a) Prasa - przede wszystkim prasa codzienna diaspory polskiej z XX w., b) Książki - druki wydane poza Krajem w pierwszej połowie XX w., c) Archiwalia - np. dokumentacja stowarzyszeń, instytucji, czy indywidualna. Natomiast siostrzaną, tj. tożsamą stroną do Polonijnej Biblioteki Cyfrowej jest platforma Wirtualnego Muzeum Polonii - projektu bazującego na zbiorach PBC.

\section{KINO I RADIO}

Po wynalezieniu druku przez Gutenberga, postępowy rozwój kinematografii był kolejnym krokiem milowym w wytworzeniu się nowego typu kultury i przemian społecznych, jakie pod jego wpływem zaszły w sektorze rozrywki. Film na początku swojego istnienia wzbudził kontrowersje, powodując mieszane uczucia a nawet przerażenie u odbiorców. Jednakże z czasem jego dynamicznej ewolucji: od filmu niemego, do dźwiękowego, czy od filmu biało-czarnego do kolorowego, zaczął stopniowo przekonywać do siebie publiczność, w efekcie stając się jedną z głównych i szeroko-dostępnych rozrywek. Film wpływa na ludzkie emocje, przeżycia czy pragnienia wywołując przy tym najróżniejsze doznania. Szczególne znaczenie w filmie ma jego przesłanie, które niesie dla widza jakąś naukę, morał,

${ }^{16}$ PBC, Polonijna Biblioteka Cyfrowa, http://www.pbc.uw.edu.pl/information.html (dostęp: 12.11.2020). 
czy myśl ${ }^{17}$. W ten sposób staje się jednym z czynników kształtujących opinię, a to spowodowało, że sztuka filmowa znalazła swoje zainteresowanie także u władz, jak i instytucji kościelnych. Począwszy od papieża Leona XIII, którego pontyfikat przypadł na początki rozwoju kinematografii - film zaczął wzbudzać duże zainteresowanie Stolicy Apostolskiej ${ }^{18}$. Pierwszy dokument odnośnie do filmowego środka przekazu wydał w 1936 roku Papież Pius XI. Jego Encyklika „Vigilanti Cura" w całości poświęcona została zjawisku i wpływowi filmowemu. Następnie, w dwadzieścia lat po jej ogłoszeniu, następca Piusa XI - Papież Pius XII ogłasza encyklikę o kinematografii, radiu i telewizji pt. „Miranda prorsus”. W jej treściach dotyczących X Muzy zawarte są wskazania dotyczące moralnej oceny filmów ${ }^{19}$. Ponadto ważnymi dokumentami odwołującymi się do istoty kina (a także radia) są corocznie wygłaszane orędzia papieskie z okazji Dnia Środków Społecznego Przekazu. Owe wydarzenie w całości poświęcone mass mediom: prasie, radiu, telewizji i kinematografii, zostało ustanowione na II Soborze Watykańskim, a sformułowane w postaci Dekretu Inter mirifica. Na wstępie wytłumaczony został powód zainteresowań Stolicy Apostolskiej mass mediami, przytaczając treść dokumentu: „Spośród podziwu godnych wynalazków techniki, które geniusz ludzki z pomocą Bożą w naszych zwłaszcza czasach odkrył w rzeczach stworzonych, Kościół - Matka przyjmuje i śledzi ze szczególną troską te, które odnoszą się przede wszystkim do ducha ludzkiego, a które odsłoniły nowe drogi do przekazywania z największą łatwością wszelkiego rodzaju wiadomości, myśli i wskazań. Wśród wynalazków tych najdonioślejsze są urządzenia, które z natury swej zdolne są dosięgnąć i poruszyć nie tylko jednostki, lecz także całe zbiorowości i całą społeczność ludzką, jak: prasa, kinematografia, radiofonia, telewizja i inne tym podobne"20. Z tego też względu, od 1967 roku w maju, obchodzony jest Dzień Środków Społecznego Przekazu, którego uroczystość Ojciec Święty ustanowił na niedzielę przed Zesłaniem Ducha Świętego, natomiast temat orędzia corocznie ogłaszany jest 29 września w dniu święta Archanioła Gabriela - patrona radiowców ${ }^{21}$.

${ }^{17}$ J. Ostaszewski, Rozumienie opowiadania filmowego, Kraków 1999, s. 74.

${ }^{18}$ K. Pokorna-Ignatowicz, Kościół w świecie mediów, Kraków 2002, s. 27.

${ }^{19}$ Tamże, s. 58.

${ }^{20}$ zob. Sobór Watykański II, Dekret „Inter mirifica”, https://www.paulus.org.pl/213,inter-mirifica (dostęp: 26.11.2020).

${ }^{21}$ zob. B.a, Światowy Dzień Środków Społecznego Przekazu. Historia i idea, (brak daty publ.), http://mediadlaewangelii.pl/content.php?ContentId=55 (dostęp: 26.11.2020). 
Kino i radio mają wiele cech wspólnych, począwszy od zbliżonej terminologii określającej radio w początkach jego istnienia (lata 20te) „Wielkim Ślepcem” i funkcjonującym analogicznie do tego terminem: „Wielki Niemowa” - adresowanym do filmu niemego, stosunkowo oswojonego w tym okresie ${ }^{22}$. Poza tym owe podobieństwo dla kina i radia, zauważalne jest w szczególności w sile oddziaływania, gdyż obydwa medium niosą ze sobą przekaz dla odbiorców. Każde z nich funkcjonuje w służbie społeczeństwa, tj. informuje, uczy, bawi, kształci wpływając na wyobraźnie, zmysły czy postawy adresatów. Tym, co może różnić te dwa przekazy jest fakt, iż radio od początków swojego istnienia wciąż utrzymuje się na rynku medialnym i dobrze prosperuje. Adekwatnym dla tego stwierdzenia przykładem są słowa Tomasza Gobana-Klasa ukazujące fenomen radia: „Ma bowiem [radio] ponad 80 lat i trzyma się nieźle. Zupełnie nieźle, jeśli zważyć, że to nie telewizja, nie prasa, nie Internet, ale właśnie radio jest najbardziej rozpowszechnionym medium na świecie, A wyglądało na to, iż radio znajdzie się na liście tzw. martwych mediów, pospołu z filmem niemym czy telegrafem. Niemniej przetrwało i to w nie najgorszej kondycji"23. Co więcej, obraz filmowy jak i rozgłośnia radiowa bazują na zmyśle słuchu (audio), gdzie film ma większą siłę oddziaływania, gdyż wpływa na dwa zmysły: słuch (audio) i wzrok (visual). Dlatego analiza dzieła filmowego składa się na część werbalną, jak i wizualną, która następnie wpływa na kształtowanie percepcji opartej na audiowizualnym mechanizmie odbiorczym, wydobywającym informacje płynące z obrazu i dźwięku, łącząc je w jedną całość znaczeniową ${ }^{24}$. W przypadku filmu, jak i telewizji, potrzebujemy ciągłej koncentracji poznawczej, aby móc odczytać dany przekaz przesyłany z dwóch źródeł: audio i visual. Natomiast radio w swym przekazie jest mniej zachłanne i absorbujące, gdyż dociera tylko jednym kanałem komunikacyjnym - słuchem. Ponadto, bazuje na naturalnym podziale uwagi, mianowicie: tym co słyszymy i tym, co widzimy ${ }^{25}$. Ów stan naturalny „słuchania bez widzenia”, nie jest dla człowieka zjawiskiem obcym (występuje chociażby w nocy), czego odwrotnością jest właśnie film niemy

${ }^{22}$ A. Wójciszyn-Wasil, Obrazy - nie tylko w wyobraźni. Wizualna rewolucja radia, „Zeszyty Naukowe KUL" 2018 nr 1 (241), s. 373.

${ }^{23}$ T. Goban-Klas, Radiomorfoza w kontekście ewolucji, adaptacji i konwergencji mediów, „Studia Medioznawcze” 2006 z 3 (26), s. 16.

${ }^{24}$ M. Hopfinger, Doświadczenia audiowizualne. O mediach $w$ kulturze współczesnej, Warszawa 2003, s. 23-24

${ }^{25}$ T. Goban-Klas, Radiomorfoza w kontekście ewolucji..., dz. cyt., s. 17. 
bazujący na „widzeniu bez słuchania” ${ }^{26}$. Niemniej jednak, także i w praktyce radiowej występuje silny związek pomiędzy dźwiękiem a obrazem, prezentowany przez jeden z gatunków sztuki radiowej, tzw. „słuchowisko” - wywodzące się od słowa „widowisko”. Sztuka radiowa słuchowiska miała swój początek już w latach 30. w repertuarze Polskiego Radia, którego oferta wzbogaciła się o słynny „Teatr Wyobraźni"27. Tego typu programy bazujące na dźwięku, głosie ludzkim, czy muzyce nazywane były również „Teatrem do słuchania”, czy „Kinem dla ucha”28. O powiązaniach słuchowiska i kina pisał w 1935 roku twórca danego gatunku radiowego - Antoni Bohdziewicz ${ }^{29}$, który stwierdził, iż: „Kino jest przecież z radiem mocniej spokrewnione niż jakakolwiek inna Muza! To pokrewieństwo jest podwójne: pokrewieństwo ducha, samej istoty i pokrewieństwo krwi: radio i kino muszą posługiwać się techniką: maszynką, lampką i drucikiem"30. Ponadto kontynuując, klarownie wytłumaczył zależności pomiędzy jednym a drugim: „Kino rejestruje świat ruszających się świateł i cieni - to było i jest nadal jego treścią. Radio jest takim samym kinem dla ucha i winno ogarnąć cały świat dźwięków. Żywe słowo jest dużą częścią tego świata, najważniejszą, ale nie jedyną"31.

\section{W przypadku zarówno filmu, jak i telewizji, potrzebujemy ciągłej koncentracji poznawczej, aby móc odczytać dany przekaz przesyłany $z$ dwóch źródeł: audio i visual. Natomiast radio w swym przekazie jest mniej zachłanne i absorbujące, gdyż dociera tylko jednym kanałem komunikacyjnym - słuchem.}

${ }^{26}$ P. Levinson, Miękkie ostrze, czyli historia i przyszłość rewolucji informacyjnej, Warszawa 2006, s. 174.

${ }^{27}$ D. Grzelewska, R. Habielski, A. Kozieł, J. Osica, L. Piwońska-Pykało, F. Skwierawski, Prasa, radio i telewizja w Polsce. Zarys dziejów, Warszawa 1999, s. 204.

${ }^{28}$ A. Wójciszyn-Wasil, Obrazy - nie tylko w wyobraźni..., dz. cyt., s. 375-376.

${ }^{29}$ Zob. D. Grzelewska, dz. cyt., s. 196.

${ }^{30}$ A. Bohdziewicz, Przyszłość słuchowiska radiowego, „Pion” 1935 nr 15, s. 11.

${ }^{31}$ Tamże. 
Temat kina $\mathrm{w}$ drugiej połowie XX w. zagościł w rozgłośniach radiowych, w najróżniejszych formach przekazu (recenzja, wywiad, pogadanka, nowinki filmowe, itp.). Obecność tematyki filmowej w rodzimym radiu jest już zauważalna w latach siedemdziesiątych, za przykładem „Programu Trzeciego Polskiego Radia”, w którym w 1974 roku $^{32}$ zainaugurowano cykl audycji satyrycznych pt. „Fajny film wczoraj widziałem", prowadzony przez znanych autorów i artystów, jak m.in. Andrzeja Zaorskiego i Mariana Kociniaka. Konwencją programu było prezentowanie nowych dzieł kinowych, jak i telewizyjnych w zabawny, humorystyczny sposób ${ }^{33}$. Lata 90. w radiowej „Trójce” zaowocowały kolejnym, znanym programem filmowym z 1997 roku, pt. „Trójkowo, filmowo”. Prowadzącym audycję po dziś dzień jest dziennikarz Ryszard Jaźwiński. Program ten stricte ukierunkowany jest na środowisko kinematograficzne. Przedstawiane są w nim wywiady, rozmowy z twórcami filmowymi i aktorami, ponadto relacje $\mathrm{z}$ festiwali filmowych, planów zdjęciowych, czy prezentowanie nowości kinowych. Redaktor R. Jaźwiński w radiowej „Trójce” prowadził kilka audycji o danej tematyce, jak np. „Fajny film wczoraj widziałem”, „Prosto z kina” (aktualnie, kontynuacją tego zakończonego programu jest: „Fajny film”), „Premiera tygodnia”, „Premiery filmowe”, czy wciąż nadawany program „Noc Oscarów w Trójce” ${ }^{34}$. Co więcej, audycje kulturalne - dotyczące polskiego rynku kinematograficznego obecne są w rozgłośniach ogólnopolskich, jak i lokalnych. Przykładem audycji szczebla regionalnego, jest np. Radio Kraków i nadawany w nim program pt. „Do kina, czy na film” - gdzie omawiane są premiery i nowości dużego ekranu, na które zapraszają krakowscy wielbiciele kina ${ }^{35}$. W przypadku komercyjnej rozgłośni Radia Zet, zostały poczynione jeszcze dalsze kroki - w kierunku popularyzacji rozrywki. Mianowicie w 2012 roku stacja radiowa nawiązała współpracę z portalem stopklatka.tv, który stał się patronem audycji „MultiKinoZetka”, prowadzonej przez dziennikarkę Agnieszkę Kołodziejską. Dzięki tej kolaboracji na stronie internetowej platformy

${ }^{32}$ zob. https://www.polskieradio.pl/231/4360/Artykul/1400679,60-minut-na-godzine (dostęp: 23.11.2020).

${ }^{33}$ M. Kamiński, Fajny film wczoraj widziałem... - filmowy konkurs radiowej trojki, „Filmweb" z 24.09.2002 r., https://www.filmweb.pl/news/\%22Fajny+Film+Wczoraj+Widzia\%C5 \%82em...\%22+-+filmowy+konkurs+radiowej+Tr\%C3\%B3jki-8191 (dostęp: 23.11.2020).

${ }^{34}$ Zob. Redakcja, Ryszard Jaźwiński, http://www.trojkofan.trojka.info/zespol-jazwinski-ryszard.html (dostęp: 23.11.20).

${ }^{35}$ Zob. Redakcja, Do kina czy na film, http://www.radiokrakow.pl/audycje/do-kina-czy-na-film/ (dostęp: 23.11.20). 
stopklatka.tv umieszczano wywiady dziennikarzy radiowych Radia Zet, znalazł się tam również odnośnik do stacji radiowej, którą można było posłuchać w wersji online. Natomiast na stronie www.radiozet.pl powstała zakładka „Zet Film”, zawierająca piosenki i muzykę filmową. Co więcej, wiadomości kulturalne Radia Zet dostępne na stronie internetowej radia, zostały uzupełnione o informacje na temat wybranych filmów, odsyłając przy tym czytelników do Stopklatki. Na skutek tego, radio jak i kanał internetowy specjalizujący się w tematyce filmowej, zyskały nowych odbiorców dzięki obopólnej promocji, a tym samym zaczęły budować swój wizerunek na innych płaszczyznach medialnych ${ }^{36}$.

Tematyka filmowa stała się ważnym punktem w rozgłośniach radiowych, zważywszy na stałe, piątkowe premiery kinowe, które swoją promocję miały również w radiu - temat ten po dziś dzień nie został jeszcze wyczerpany. W formie gotowych już podcastów czy audycji na żywo: dyskusji, wywiadu - dziennikarze radiowi sięgają po tematy filmowe, urozmaicając i przyciągając swoich słuchaczy zapraszanymi do studia znanymi gośćmi, jak np. reżyserzy, aktorzy, scenarzyści, czy krytycy filmowi. Najczęściej w audycjach radiowych poświęconych tematyce kina, sięga się po bieżący materiał, czyli to, co aktualnie można znaleźć w repertuarze kinowym, czy ofercie platform streamingowych: Netflixa, bądź HBO GO. Na przykładzie Radia Nowy Świat, program o filmie pt. „Raczek movie” prowadzi znany krytyk filmowy - Tomasz Raczek, w którym głównie bazuje na bieżących premierach kinowych, jak i nowościach onliene'owych. Zazwyczaj wiadomości o X muzie są przedstawione w formie recenzji, wnikliwej krytyki filmu bądź dyskusji na temat wybranego dzieła filmowego z zaproszonym gościem ${ }^{37}$.

Dyskurs medialny, w tym przypadku radiowy (język mediów), jest w dużej mierze zależny od stylu i formy wypowiedzi prezentowanej przez dziennikarza, czy prowadzącego audycję, a przy tym od konwencji danej stacji radiowej. $\mathrm{Na}$ przykładzie krytyków filmowych tj.: Bożeny Janickiej, dyskutującej o polskim filmie w Radiu TOK FM ${ }^{38}$, czy wspomnianym T. Raczku z Radia Nowy Świat - z reguły powyżsi dziennikarze posługują się językiem poprawnej polszczyzny, a nad-

${ }^{36}$ P. Czarnek, Rodzaje rozrywki w polskiej radiofonii komercyjnej, Łódź 2014, s. 249.

${ }^{37}$ Audycje radiowe „Raczek movie” prowadzone są w niedzielę o godzinie 13:00, a także dostępne w formie podcastów na stronie internetowej www.nowyswiat.online.pl, w zakładce „Podcasty”.

${ }^{38}$ Podcasty radiowe zapisane zostały i są dostępne na stronie radia: https://audycje. tokfm.pl/gosc/997,Bozena-Janicka (dostęp: 5.05.2021). 
to profesjonalnym - gdyż operują terminologią filmoznawczą, medialną, a przy tym - językiem czytelnym i zrozumiałym chociażby dla laików filmowych (co można zauważyć w wypowiedziach medialnych danych krytyków). Niemniej jednak w audycjach radiowych XXI wieku (nie tylko filmowych), zauważalny jest zwrot w kierunku potoczności, przy użyciu języka kolokwialnego, nasyconego neologizmami czy anglicyzmami. 0 tym zjawisku referuje w swojej publikacji Jerzy Podracki w Potoczne elementy językowe w polszczyźnie radia i telewizji ${ }^{39}$, czy Katarzyna Mosiołek-Kłosińska w Wulgaryzacja języka w mediach ${ }^{40}$. Masowe upowszechnienie języka polskiego w radioodbiornikach (ale także prasie, telewizji, czy internecie) spowodowało, że dyskurs radiowy przekazywany jest w wersji mniej lub bardziej poprawnej, wysokiej, niskiej, eleganckiej, profesjonalnej, czy nawet wulgarnej.

Nic więc dziwnego, że Radio Watykańskie, dla którego temat kultury, sztuki, mediów, a tym bardziej przekazów audiowizualnych nie jest i nie był obcy (poruszane od wielu dziesięcioleci tematy medium i kina na łamach encyklik papieskich, czy na Światowych Dniach Środków Społecznego Przekazu) - sięgnęło po temat filmu, powierzając mu przestrzeń w autorskich (dedykowanych) audycjach radiowych.
Masowe upowszechnienie języka polskiego w radioodbiornikach (ale także prasie, telewizji, czy internecie) spowodowało, że dyskurs radiowy przekazywany jest w wersji mniej lub bardziej poprawnej, wysokiej, niskiej, eleganckiej, profesjonalnej, czy nawet wulgarnej.

${ }^{39}$ Zob. J. Podracki, Potoczne elementy językowe w polszczyźnie radia i telewizji, w: Język w mediach masowych, red. J. Bralczyk, K. Mosiołek-Kłosińska, Warszawa 2000, s. 135-142.

${ }^{40}$ Zob. K. Mosiołek-Kłosińska, Wulgaryzacja języka $w$ mediach, w: Język $w$ mediach..., dz. cyt., s. $112-119$. 


\section{4. „KINO - WEHIKUŁ LUDZKICH TĘSKNOT” - ANALIZA AUDYCJI}

Pierwotnie audycje cyklu „Kino - wehikuł ludzkich tęsknot” zapisane były w serii odcinków na jedenastu płytach CD (po dziś dzień własność polskiej sekcji Radia Watykańskiego). W ramach projektu MEN „Zachować i promować polskie dziedzictwo narodowe - digitalizacja i opracowanie naukowe archiwaliów Polskiej Sekcji Radia Watykańskiego", cykl audycji radiowych polskiej sekcji radia watykańskiego został zdigitalizowany i umieszczony w tzw. rubrykach, w wolnym dostępie na stronie Polonijnej Biblioteki Cyfrowej. Zamieszczonych rubryk z audycjami cyklu jest 11, każda z nich posiada po kilka odcinków. Pierwsza zawiera osiem odcinków, natomiast każde kolejne do ósmej - liczą po siedem słuchowisk, zaś trzy ostatnie numery rubryk $(9,10,11)$ mają ich sześć. Czas trwania pojedynczych materiałów audio oscyluje w granicach od 8 do 10 minut. Nagrania są zwięzłe, zawierają ścieżkę muzyczną, fragmenty audialne scen z filmów (zazwyczaj są to dialogi bohaterów), jak i zwieńczający każdy odcinek morał bądź przesłanie przedstawione przez lektora. W przygotowaniu wszystkich odcinków cyklu został zastosowany zabieg klamry kompozycyjnej, występujący w postaci gotowego podkładu muzycznego. Każda z audycji radiowych rozpoczyna się i kończy tym samym fragmentem muzycznym, który łączy w sobie soundtrack dwóch popularnych filmów. Pierwszy utwór pt. Concerning Hobbits pochodzi z filmowej Trylogii „Władcy Pierścieni: Drużyna Pierścienia” z 2001 roku, natomiast druga kompozycja pt. The Battle z filmu „Gladiator” z 2000 roku. Muzyka we wstępie każdej z audycji od razu wprowadza odbiorcę $w$ filmowy świat, pobudza zmysł słuchu, który pełni rolę kluczową dla odbioru treści i przekazów audialnych.

Wszystkie 11 rubryk z audycjami „Kino - wehikuł ludzkich tęsknot” zostało zrealizowanych przez wspomnianego w publikacji o. Danilewicza we współpracy z redaktorem Janem Pniewskim (pracownik Redakcji Katolickiej Radia Polskiego $^{41}$ ), który był odpowiedzialny za opracowanie i przygotowanie materiałów. Nazwiska, jak i funkcje obydwu autorów wspominane są na zakończenie każdego odcinka.

Według informacji ze strony Wirtualnego Muzeum Polonii, „Kino - wehikuł ludzkich tęsknot” w programie polskiej sekcji radia watykańskiego emitowany był

${ }^{41}$ zob. Redakcja, $O$ nas, https://www.polskieradio.pl/37,Redakcja-Programow-Katolickich/900,0-nas (dostęp: 26.11.2020).

KULTURA - MEDIA - TEOLOGIA 45/2021 
co tydzień w niedzielę ${ }^{42}$. Emisja pierwszego odcinka miała miejsce 14 listopada 2004 roku, ostatnia zaś 24 czerwca 2007 roku $^{43}$ Cały materiał został zachowany na płytach CD i do dziś pozostaje własnością Radia Watykańskiego. Audycje w swojej strukturze wyróżniają się zauważalną powtarzalnością schematu. Po pierwsze, głównym tematem rozważań dla każdego słuchowiska jest jeden, wybrany przez autorów film. Dzieła te pochodzą z różnych przedziałów czasowych, przeważnie są one powiązane z konkretną cezurą czasową w dziejach kina i filmu. Ponadto dobór obrazów filmowych jest chronologiczny, tzn. z każdym kolejnym odcinkiem przedstawiane jest coraz to młodsze dzieło filmowe (jednakże występują wyjątki od tej reguły). Poczynając od samych początków kina - jego narodzin pod koniec XIX wieku, a na latach 70-tych kończąc. Ponad 70letnia historia kina zawarta jest w 74 słuchowiskach cyklu audycji „Kino - wehikuł ludzkich tęsknot”. Dzieła filmowe pochodzą od najznakomitszych twórców kina: europejskiego, amerykańskiego, rosyjskiego, finlandzkiego, szwedzkiego, itp. Niezaprzeczalnie audycje te zawierają wspomnienie o wybitnych twórcach, jak i dziełach światowej kinematografii. W repertuarze filmowym omawianych audycji znajdziemy wybitne nazwiska twórców i pionierów światowej kinematografii, jak np.: Siergiej Einstein, Orson Welles, Akira Kurosawa, Federico Fellini, Ingmar Bergman, Alfred Hitchcock, Stanley Kubrick, Michaił Kałatozow, Michalis Kakogiannis i wielu innych wybitnych reżyserów ${ }^{44}$. Niektóre z nazwisk autorów filmowych powtarzają się w kilku słuchowiskach, jak np. Francis Ford Coppola, którego „Ojciec chrzestny” omawiany jest w odcinku trzecim (rubryka nr 10), a „Czas apokalipsy” w piątym (rubryka nr 11). Podobną sytuację mamy z filmami Frieda Zinnemanna, z których „W samo południe” zostało przedstawione w odcinku czwartym (rubryka nr 4.) a obraz „Oto jest głowa zdrajcy” w odcinku szóstym (rubryka nr 7). Po drugie każde ze słuchowisk zawiera krótkie wprowadzenie do podejmowanego w danym materiale filmu, przedstawiane przez lektora. Przedmowa zawiera zazwyczaj treści opisujące ogólną sytuację kina umiejscowioną w wybranej cezurze czasowej, z której pochodzi wyróżniony obraz filmowy. Tym samym najpierw przedstawiony zostaje zarys historyczny, który stanowi tło dla wprowadzenia i omówie-

${ }^{42}$ W. Nowakowska, Papieska rozgłośnia, „Niedziela” 12.2007 r., https://www.niedziela. pl/artykul/81727/nd/Papieska-rozglosnia (dostęp: 19.11.2020).

${ }^{43}$ Zob. http://muzeumpolonii.uw.edu.pl/?page_id=2550 (dostęp: 28.11.2020).

${ }^{44}$ Zob. tabela 1. 
nia głównego tematu słuchowiska - filmu. Co więcej, owa schematyczność dotyczy także przedmiotu rozważań każdego odcinka, czyli zaprezentowania dzieła i problemowego jego ujęcia. Wspomniana „problematyczność” filmu przeważnie wynika z podejmowanej analizy akcji dzieła i działań głównego bohatera - jego emocjonalnej strony, zachowania, jak również dokonanej przemiany. Lektorzy od ogółu do szczegółu podążają w swoim zachowanym schemacie przedstawianych treści, wyciągając z omawianego filmu naukę, czy uniwersalne przesłanie - pozostawiając widza sam na sam z własnymi przemyśleniami.

Zakres tematyczny cyklu audycji, jak zostało powyżej wspomniane, obejmuje ponad 70 lat historii kina. Audycje tworzą (względnie) chronologiczny ciąg wydarzeń, odnosząc się do każdego dziesięciolecia z dorobku światowej kinematografii: począwszy od lat 20., na 70. kończąc. Wyjątek stanowi tu szczególna audycja, inaugurująca cykl poświęcony kinu, mianowicie pierwszy odcinek pod tytułem: „wprowadzenie”, prezentujący film „Pasja” w reż. Mela Gibsona z 2004 roku. Wybór danego dzieła wyróżnia się pośród przyjętej chronologii filmowych odcinków. Powodem tego może być fakt, iż pierwszy materiał cyklu „Kino - wehikuł ludzkich tęsknot" został wyemitowany dziewięć miesięcy po głośnej premierze filmu M. Gibsona ${ }^{45}$. Ponadto, jak już zostało wspomniane we „wprowadzeniu” „Pasja” swoją formą, jak i treścią dotyka uniwersalnych kwestii odnoszących się do istoty kina. Jak sami narratorzy podkreślają: „takie też jest kino - raz jarmarczne, raz ambitne, między tanią rozrywką a głębokim namysłem otaczającego świata. Odnajdujemy $\mathrm{w}$ nim gatunki szlachetne i te schlebiające pospolitym gustom. $\mathrm{W}$ jednych i w drugich można znaleźć arcydzieła na równi $\mathrm{z}$ falsyfikatami"46. Tymi słowami lektor zaprasza słuchaczy na cotygodniowy cykl audycji pt. „Kino - wehikuł ludzkich tęsknot”. W nawiązaniu do powyższych treści, można więc stwierdzić, iż film M. Gibsona idealnie wpasowuje się w charakter audycji rozgłośni polskiej sekcji radia watykańskiego - jednego z reprezentatywnych medium stolicy apostolskiej. Adaptacja ostatnich godzin z życia Jezusa zalicza się do gatunku kina religijnego, a uściślając - do filmu biblijnego, gdyż „Pasja” stricte odwołuje się do treści biblijnych (Nowy Testament). Według Iwony Kolasińskiej,

${ }^{45}$ Światowa premiera filmu „Pasja” odbyła się 24 lutego 2004 roku, zob. https://www. filmweb.pl/film/Pasja-2004-38233 (dostęp: 30.11.2020).

${ }^{46}$ Na podstawie audycji A. Danilewicz, „Wprowadzenie - „Pasja” Mela Gibsona”, Kino wehikuł ludzkich tęsknot, data emisji: 14.11.2004, 10', http://muzeumpolonii.uw.edu.pl/?page_id=2550 (dostęp: 30.11.2020). 
autorki publikacji pt. film biblijny, zainteresowanie ekranizacją treści Nowego Testamentu przypada głównie na lata: 50., 60. i 70. - w szczególności zauważalne w kinie amerykańskim. Przykładem tego jest film George’a Stevensa pt. „Opowieść wszech czasów” z 1965 roku, czy ekranizacja sławnego musicalu „Jesus Christ Superstar" w reżyserii Normana Jewisona z 1973 roku $^{47}$. Jednakże coraz to nowsze produkcje filmów biblijnych, np. z lat 90., wyróżniały się już nowymi tendencjami w przedstawianiu biblijnych tematów: m.in. współczesnymi stylami i technikami. Adaptacje wątków biblijnych ostatniej dekady XX wieku, urastały do

\section{Ponad 70-letnia historia kina zawarta jest w 74 słuchowiskach cyklu audycji „Kino - wehikuł ludzkich tęsknot". Audycje tworzą (względnie) chronologiczny ciąg wydarzeń, odnosząc się do każdego dziesięciolecia z dorobku światowej kinematografii: począwszy od lat 20-tych, na 70tych kończąc.}

rangi superprodukcji, $\mathrm{z}$ charakterystycznym dla tego typu formatu rozmachem inscenizacyjnym i produkcyjnym ${ }^{48}$. Przykładem wspomnianych wielkoformatowych produkcji jest dzieło cenionego reżysera Martina Scorsese pt. „Ostatnie kuszenie Chrystusa” z 1988 roku, czy wspomniana „Pasja” M. Gibsona. Co ciekawe, oba te filmy skupiają się na ostatnich chwilach z życia Jezusa Chrystusa w podobny, niezwykle przeszywający i emocjonalny sposób. Co więcej, wywołały niemało kontrowersji i dyskusji, m.in. w środowisku filmoznawczym, teologicznym i naukowym. Bowiem to właśnie „Pasji” zarzucano zbytnią dosłowność przekazu i niezwykły brutalizm obrazu. W pierwszym odcinku otwierającym cykl audycji,

${ }^{47}$ Ł. Cieślak, Najlepsze filmy religijne. Top 20 filmów, które warto obejrzeć, „Filmweb” z 31.05.2020 r., https://www.filmweb.pl/news/Najlepsze+filmy+religijne.+Top+20+film\%C3 \%B3w\%2C+kt\%C3\%B3re+warto+obejrze\%C4\%87-137946 (dostęp: 2.12.2020).

${ }^{48}$ I. Kolasińska, Film biblijny, w: Wokół kina gatunków, red. K. Loska, Kraków 2001, s. 233-234. 
film ten nie jest poddany krytyce, lecz zostaje przedstawiony jako przykład istoty i funkcji kina, które od początku swojego istnienia bywa zaskakujące i różnorodne, dzięki czemu każdy może znaleźć w nim coś dla siebie.

Pierwsza rubryka zawiera osiem odcinków (w przeważającej części są to filmy produkcji amerykańskiej), w większości odnoszących się do początków kina. Wyjątek stanowi audycja szósta, przypadająca na Święta Bożego Narodzenia (data emisji: 26.12.2004), w której porównane zostały ze sobą dwa dzieła filmowe, stanowiące adaptacje powieści Charlesa Dickensa, pt. „Opowieść wigilijna”. Oba obrazy tożsame są pod względem tematyki filmu, jednakże odmienne w stylu prezentowania. Filmy, o których mowa, to dzieła Richarda Donnera pt. „Świąteczne show” z 1988 roku, jak i „Opowieść wigilijna” Davida Jonesa z 1999 roku $^{49}$. Kolejnym odstępstwem chronologicznym jest audycja noworoczna (odcinek siódmy) z dnia 2 stycznia 2005 roku, zatytułowana: „Dar czasu”. W tym materiale omawiane jest dzieło Harolda Ramisa pt. „Dzień Świstaka” z 1993 roku. Przytoczone powyżej wyjątki można uznać za tzw. audycje tematyczne, które stricte odwołują się do danego wydarzenia: święta kościelnego, czy tradycji świętowanej w rzeczywistym czasie emisji danej audycji. Warto dodać, że są to wydarzenia związane z uroczystymi obrzędami obchodzonymi w Kościele katolickim (w dniu Bożego Narodzenia jest to msza pasterska - pasterka ${ }^{50}$, a w nowy rok - msza noworoczna, jako błogosławieństwo na nowy rok). Filmy z rubryki pierwszej (ze wspomnianymi dwoma wyjątkami) pochodzą z pierwszego trzydziestolecia, jak i ostatniego trzydziestolecia XX wieku ${ }^{51}$. Omawiane są obrazy filmowe początków kina: amerykańskiego „Gorączka złota” z 1925 roku, radzieckiego „Pancernik Potiomkin” z 1925 roku, czy z czołowych osiągnięć ekspresjonizmu niemieckiego w filmie "Gabinet doktora Caligari” z 1920 roku. Dziełem zamykającym tę część, jest obraz wiedeńskiego reżysera Fritza Langa, pt. „M - morderca” z 1931 roku,

${ }^{49} \mathrm{Na}$ podstawie audycji A. Danilewicz, „Boże Narodzenie”, kino - wehikuł ludzkich tęsknot, data emisji: 26.12.2004, 10'49", http://muzeumpolonii.uw.edu.pl/?page_id=2550 (dostęp: 15.12.2020).

${ }^{50}$ Pasterka jest to uroczysta, pierwsza msza święta otwierająca w Kościele katolickim oktawę liturgicznych obchodów Bożego Narodzenia, zob. https://web.archive.org/ web/20130731061856/http://www.xn--witaboegonarodzenia-rrc79k7u.pl/pasterka/ (dostęp: 16.12.2020).

${ }^{51}$ zob. tabela 1. 
pierwszy film dźwiękowy w filmografii autora, jak i dzieło rozpoczynające nową tematykę filmową $\mathrm{w}$ danym cyklu audycji.

Filmy zaprezentowane $\mathrm{w}$ rubryce drugiej stanowią syntezę tego, co działo się na przełomie lat 30. i 40. w XX wieku. W tej części cyklu mamy do czynienia $\mathrm{z}$ anglosaskimi klasykami, należących do kanonu kina światowego. To m.in. „Przeminęło z wiatrem” w reż. Victora Fleminga z 1939 roku, „Obywatel Kane” Orsona Wellesa z 1941 roku, czy „Casablanca” Michaela Curtiza z 1942 roku. Tych siedem przedstawionych filmów rubryki drugiej, w większym bądź mniejszym stopniu, odwołuje się do skutków kryzysu lat $30 .{ }^{52}$. Podejmowane w audycjach tematy odnoszą się m.in. do szeroko pojętej niesprawiedliwości (prawnej, systemowej), zniewolenia człowieka, biedy, nędzy czy wolności jednostki ${ }^{33}$. Z kolei rubryka trzecia zawiera przełamującą (amerykańską dominację) różnorodność narodową filmów. Otóż w materiałach pojawiają się dzieła włoskich, finlandzkich czy francuskich twórców i ich dzieła przełomu lat 40. i 50., m.in.: „Rzym, miasto otwarte” Federico Rosseliniego, „Niepotrzebni mogą odejść” Carola Reeda, czy „Cena strachu" Henri Clousette'a. Odstępstwem od wspomnianego porządku czasowego jest dzieło finlandzkiego reżysera Aki Kaurismakiego pt. „Człowiek bez przeszłości” z 2002 roku. Choć obraz A. Kaurismakiego dzieli od pozostałych filmów kilka dekad, niemniej jednak tematycznie wpasowuje się do podjętej problematyki rubryki trzeciej. W tej części lektorzy zwracają szczególną uwagę na niezbędność każdego życia ludzkiego: dobrego, jak i złego. Kolejne z opracowanych rubryk audycji, przywołują coraz to nowych twórców kina światowego, jak i ich kultowe dzieła. W części czwartej i piątej mamy przybliżone retrospekcje klasyki kina lat 50.. Następnie w rubrykach sześć, siedem i dziewięć zaprezentowane są filmy z kanonów kina lat 60.: „Co się zdarzyło Baby Jane”, „Goście wieczerzy pańskiej”, czy „Sklep przy głównej ulicy”. Część ósma natomiast, wykracza poza obowiązujący w większości rubrykach schemat chronologiczny. Prezentowane w niej filmy pochodzą z kilku dziesięcioleci, mianowicie z lat: 60., 70. jak i jedno dzieło pochodzące z lat 80. - pt. „Legenda o świętym pijaku” w reż. Ermanno Olmi z 1988 roku (odcinek nr 4). Przytoczona audycja miała swoją transmisję ostatniego dnia

${ }^{52}$ Wielki kryzys gospodarczy, który miał miejsce w 1929 roku i objął wszystkie państwa z wyjątkiem ZSRR. W audycjach z rubryki drugiej, głównie omawiane są skutki kryzysu gospodarczego w USA.

${ }^{53}$ A. Danilewicz, Kino - wehikuł ludzkich tęsknot ['2], [Audio], 2005, http://www.pbc. uw.edu.pl/13823/ (dostęp: 15.12.20). 
mijającego roku, tj. 31 grudnia 2006. Można więc przypuszczać, że film francuskiego reżysera został specjalnie wybrany na daną okazję - pożegnania ze starym a przywitania nowego roku. Zważywszy na fabułę, jak i przekaz, cały film (jak trafnie zauważyli lektorzy) jest pełen cudów, nadziei i łaski bożej - wartości idących wraz z nowym rokiem ${ }^{54}$. Ostatnie dwie rubryki (10 i 11) cyklu Kino - wehikuł ludzkich tęsknot, przywołują wspomnienia popularnych filmów z klasyki kina amerykańskiego z lat 70.. W tych dwóch, zwieńczających cykl rubrykach, przedstawione zostały obrazy, które w myśli filmoznawczej (teorii, historii i krytyce filmowej) po dziś dzień uważane są za ponadczasowe. To m.in.: „Brudny Harry” Dog Siegela z 1971 roku, „Ojciec Chrzestny” Francisa Forda Coppoli z 1972 roku, „Piknik pod wiszącą skałą” Petera Weira 1975 roku, „Lot nad kukułczym gniazdem” Milosa Formana z 1975 roku, „Taksówkarz” Martina Scorsese z 1976 roku, czy „Stalker” Andrieja Tarkowskiego z 1979 roku.

Jak już zostało wspomniane, zestawione filmy tegoż cyklu audycji są niezwykle zróżnicowane pod względem narodowościowym (kraj produkcji), jak również gatunkowym. Patrząc na rodzaj filmu, mamy do czynienia z najróżniejszymi gatunkami występującymi jeszcze za czasów tzw. starego kina (film czarno-biały, niemy), jak również w okresie pionierskich technik filmowych na miarę XX wieku. W materiałach audio cyklu „Kino - wehikuł ludzkich tęsknot” wyróżnione gatunki, to np.: dramat („Grono gniewu”, „Piłat i inni”), melodramat („Przeminęło z wiatrem”, „Lecą żurawie”), thriller („M - morderca”, „Wyznaję”), romans („Afrykańska królowa”), komedia („Niech żyje wolność”, „O uroczystości i gościach”), film noir („Sokół maltański”, „Bulwar zachodzącego słońca”), horror („Gabinet doktora Caligari”), film gangsterski („, Mały Cezar”, „Ojciec chrzestny”), film biograficzny („Kleopatra”, „Andriej Rublow”), czy także western („W samo południe”) ${ }^{55}$. Cykl "Kino - wehikuł ludzkich tęsknot” nie zawęża się wyłącznie do dzieł religijnych, biblijnych. Według autorki jest to przekrój klasyki filmów światowej kinematografii. Wszystkie filmy występujące w 11 rubrykach, tj. w 74 odcinkach cyklu audycji „Kino - wehikuł ludzkich tęsknot”, zostały sporządzone w formie tabeli

${ }^{54} \mathrm{Na}$ podstawie audycji A. Danilewicz, „Legenda o świętym pijaku”, kino - wehikuł ludzkich tęsknot, data emisji: 31.12.2006, 9'37", http://muzeumpolonii.uw.edu.pl/?page_id=2550 (dostęp: 15.12.2020).

${ }^{55}$ Zob. tabela 1. 
(z podziałem na: tytuł filmu, reżysera, kraj, rok produkcji i gatunek), która została umieszczona na końcu artykułu.

\section{ZAKOŃCZENIE}

Cykl audycji „Kino - wehikuł ludzkich tęsknot” stanowi treściwy przewodnik po dziedzictwie światowej kinematografii. Na podstawie wybranych filmów z okresu lat 20tych-70-tych, pozwala w sposób zwięzły i rzeczowy zapoznać się z historią kina światowego.

Projekt audycji radiowych tworzą filmy odmiennego pochodzenia: japońskiego, finlandzkiego, szwedzkiego, rosyjskiego, australijskiego, brytyjskiego, amerykańskiego i europejskiego. W materiałach radiowych przedstawione zostały sylwetki najważniejszych międzynarodowych reżyserów XX wieku. Omawiane filmy w 74 słuchowiskach, osadzone zostały w znaczących cezurach czasowych, uwarunkowanych wydarzeniami kulturalnymi, społecznymi, gospodarczymi, jak i politycznymi (tj. narodziny kina, zmierzch filmu niemego, I i II wojna światowa, kryzys gospodarczy lat 30., itp.) Zamierzenie bądź nie - cykl audycji stanowi podstawę historii kina światowego - zmieniających się trendów, technik filmowych, nowinek cyfrowych, jak i znaczącego postępu w dziedzinie kinematografii na przestrzeni kilku dziesięcioleci. Przedstawiona za pomocą słuchowisk radiowych historia została opowiedziana w sposób przystępny, za pomocą zrozumiałego i czytelnego języka narracji. Co więcej, zgodność tematyki materiału z osobą realizatora audycji: o. Danilewicza, nie powinna pozostawiać żadnych wątpliwości, zważywszy na ojca doświadczenie w pracy nad środkami społecznego przekazu (prasa, radio i telewizja).

Nawiązując zaś do przewagi filmów produkcji amerykańskiej (widocznej w szczególności w pierwszych dwóch rubrykach z audycjami), autorka zwraca uwagę na nieobecność a zarazem niedosyt polskich obrazów filmowych w prezentowanym cyklu. Filmów z rodzimej produkcji w całym zestawieniu jest tylko jeden - „Piłat i inni” w reż. Andrzeja Wajdy z 1972 roku $^{56}$. Natomiast w odcinku trzecim, rubryki ósmej przedstawiony został film pt. „Matnia”, polskiego twórcy filmowego - Romana Polańskiego. Jednakże film ten jest produkcją zagraniczną

${ }^{56}$ Zob. tabela 1.

KULTURA - MEDIA - TEOLOGIA 45/2021 
(Wielka Brytania), w którym również obsada filmu składa się z artystów obcojęzycznych (francuskich i brytyjskich).

Cykl audycji „Kino - wehikuł ludzkich tęsknot” polskiej sekcji radia watykańskiego, zachowuje i chroni polskie dziedzictwo kulturowe. Idea cyfryzacji mediów - w tym przypadku audycji radiowych - pozwala skatalogować i uporządkować materiał w jednym miejscu, co dla popularyzacji nauki, jak i dla celów dydaktycznych czy badawczych jest znaczące i potrzebne - w dużej mierze ułatwiając i umożliwiając szybki do nich dostęp. Ponadto, przedłożona publikacja otwiera pole do dalszych badań w dyscyplinie nauki o komunikowaniu społecznym i mediach, na wielu płaszczyznach, m.in.: analizy audycji radiowych (w ujęciu stricte metodologicznym, jak i praktycznym), związku kina i radia czy kwestii działalności polskiej sekcji radia watykańskiego, a tym samym do polemiki nad materiałami polskiej sekcji radia watykańskiego, które w znaczący sposób wzbogaciły zasoby Polonijnej Biblioteki Cyfrowej.

\section{BIBLIOGRAFIA}

Brzozowski J., 75 lat Polskiej Prowincji Zgromadzenia Słowa Bożego (cz. I), „Misjonarz” 2012 z. 1.

Cieślak Ł, Najlepsze filmy religijne. Top 20 filmów, które warto obejrzeć, „Filmweb” z 31.05.2020 r., https://www.filmweb.pl/.

Czarnek P., Rodzaje rozrywki w polskiej radiofonii komercyjnej, Łódź 2014.

Dobrowolski T., 60 lat polskiej sekcji radia watykańskiego, „Opoka” z 12.02.1999 r., https:// opoka.org.pl/.

Goban-Klas T., Radiomorfoza w kontekście ewolucji, adaptacji i konwergencji mediów, „Studia Medioznawcze" 2006 z. 3 (26).

Grzelewska D., Habielski R., Kozieł A., Osica J., Piwońska-Pykało L., Skwierawski F., Prasa, radio i telewizja w Polsce. Zarys dziejów, Warszawa 1999.

Hopfinger M., Doświadczenia audiowizualne. O mediach $w$ kulturze współczesnej, Warszawa 2003.

Jaroszyński J., Misja Polskiej Sekcji Radia Watykańskiego, „Kwartalnik Nauk o Mediach” 2016 z. 3, http://knm.uksw.edu.pl/.

Kamiński M., Fajny film wczoraj widziałem... - filmowy konkurs radiowej trojki, „Filmweb” z 24.09.2002 r., https://www.filmweb.pl/.

Kolasińska I., film biblijny, w: Wokół kina gatunków, red. K. Loska, Kraków 2001.

Levinson P., Miękkie ostrze, czyli historia i przyszłość rewolucji informacyjnej, Warszawa 2006.

Ostaszewski J., Rozumienie opowiadania filmowego, Kraków 1999.

Pokorna-Ignatowicz K., Kościół w świecie mediów, Kraków 2002. 
Mosiołek-Kłosińska K., Wulgaryzacja języka w mediach, w: Język w mediach masowych, red. J. Bralczyk, K. Mosiołek-Kłosińska, Warszawa 2000.

Nowakowska W., Papieska rozgłośnia, „Niedziela” z 12.2007 r., https://www.niedziela.pl/. Podracki J., Potoczne elementy językowe w polszczyźnie radia i telewizji, w: Język w mediach masowych, red. J. Bralczyk, K. Mosiołek-Kłosińska, Warszawa 2000.

Szczepaniak K., Zastosowanie analizy treści w badaniach artykułów prasowych - refleksje metodologiczne, „Acta Universitatis Lodziensis, Folia Sociologica” 2012, z. 42.

Wójciszyn-Wasil A., Obrazy - nie tylko w wyobraźni. Wizualna rewolucja radia, „Zeszyty Naukowe KUL" 2018, nr 1 (241).

https://www.filmweb.pl/

https://info.wiara.pl/

http://www.mediadlaewangelii.pl/

http://www.misjonarz.pl/

http://muzeumpolonii.uw.edu.pl/

https://www.paulus.org.pl/

http://www.pbc.uw.edu.pl/

https://www.polskieradio.pl/

http://www.radiokrakow.pl/

https://www.rownoleznik.werbisci.pl/

https://www.tokfm.pl/

http://www.trojkofan.trojka.info/

https://twitter.com/

https://www.zyciezakonne.pl/

Tabela 1. Zestawienie filmów z audycji „Kino - wehikuł ludzkich tęsknot”

\begin{tabular}{|c|c|c|c|}
\hline Tytuł Filmu & Reżyser & $\begin{array}{l}\text { Kraj pochodzenia } \\
\text { i rok produkcji }\end{array}$ & Gatunek \\
\hline \multicolumn{4}{|l|}{ CD 1.} \\
\hline 1. Pasja & Mel Gibson & USA/2004 & Biblijny \\
\hline 2. Nicklodeon & Peter Bogdanowicz & USA/1976 & Komedia \\
\hline 3. Gorączka złota & Charlie Chaplin & USA/1925 & Komedia \\
\hline 4. Gabinet dr Caligari & Robert Wiene & Niemcy/1920 & Horror \\
\hline 5. Pancernik Potiomkin & Siergiej Eisenstein & ZSRR/1925 & Dramat historyczny \\
\hline 6. Opowieść wigilijna & David Jones & USA/1999 & Dramat \\
\hline 7. Wigilijne Show & Richard Donner & USA/1988 & \\
\hline 8. Dzień Świstaka & Harold Ramis & USA/1993 & Komedia romantyczna \\
\hline 9. M - morderca & Fritz Lang & Niemcy/1931 & Thriller \\
\hline \multicolumn{4}{|l|}{ CD 2.} \\
\hline 10. Niech żyje wolność & Rene Clair & Francja/1931 & Komedia/musical \\
\hline 11. Mały Cezar & Mervyn Leroy & USA/1931 & Gangsterski \\
\hline 12. Przeminęło z wiatrem & Victor Fleming & USA/1939 & Melodramat \\
\hline 13. Obywatel Kane & Orson Welles & USA/1941 & Dramat \\
\hline 14. Grono gniewu & John Ford & USA/1940 & Dramat \\
\hline
\end{tabular}


Anita Zawisza, O kinie w Radiu Watykańskim - analiza treści audycji radiowych...

\begin{tabular}{|c|c|c|c|}
\hline Tytuł Filmu & Reżyser & $\begin{array}{l}\text { Kraj pochodzenia } \\
\text { i rok produkcji }\end{array}$ & Gatunek \\
\hline 15. Sokół Maltański & John Houston & USA/1941 & Kryminał/ film noir \\
\hline 16. Casablanca & Michael Curtiz & USA/1942 & Melodramat \\
\hline \multicolumn{4}{|l|}{ CD 3.} \\
\hline 17. To wspaniałe życie & Frank Capra & USA/1946 & Dramat/ fantasy \\
\hline 18. Rzym, miasto otwarte & Federico Rosseliniego & Włochy/1945 & Dramat wojenny \\
\hline 19. Umberto D. & Vittorio de Sica & Włochy/1952 & Dramat obyczajowy \\
\hline 20. Człowiek bez przeszłości & Aki Kaurismaki & Finlandia/2002 & Dramat/ komedia \\
\hline 21. Na nadbrzeżach & Elia Kazan & USA/1954 & Dramat \\
\hline $\begin{array}{l}\text { 22. Niepotrzebni mogą } \\
\text { odejść }\end{array}$ & Carol Reed & Wielka/Brytania 1947 & Film noir \\
\hline 23. Cena strachu & Henri Clousette & Francja/1953 & Przygodowy/ thriller \\
\hline \multicolumn{4}{|l|}{ CD 4.} \\
\hline $\begin{array}{l}\text { 24. Bulwar zachodzącego } \\
\text { słońca }\end{array}$ & Billy Wilder & USA/1950 & Dramat/ film noir \\
\hline 25. Rashomon & Akira Kurosawa & Japonia/1950 & Dramat \\
\hline 26. Afrykańska królowa & John Huston & USA/1951 & Komedia/ romans \\
\hline 27. W samo południe & Fried Zinnemann & USA/1952 & Western \\
\hline 28. La strada & Federico Fellini & Włochy/1954 & Dramat \\
\hline 29. Wieczór kuglarzy & Ingmar Bergman & Szwecja/1953 & Dramat \\
\hline 30. Wyznaję & Alfred Hitchcock & USA / 1953 & Thriller \\
\hline \multicolumn{4}{|l|}{ CD 5.} \\
\hline 31. Buntownik bez powodu & Nicolas Ray & USA/1955 & Dramat \\
\hline 32. Ucieczka skazańca & Robert Bresson & Francja/1956 & Dramat wojenny \\
\hline 33. Siódma pieczęć & Ingmar Bergman & Szwecja/1957 & Dramat \\
\hline 34. Lecą żurawie & Michaił Kałatozow & ZSRR/1957 & Melodramat \\
\hline 35. Most na rzece Kwai & David Lean & USA/1957 & Dramat/ przygodowy \\
\hline 36. Ścieżki chwały & Stanley Kubrick & USA/1957 & Dramat wojenny \\
\hline 37. Hiroszima moja miłość & Alain Resnais & Francja/1959 & Dramat/ romans \\
\hline \multicolumn{4}{|l|}{ CD 6.} \\
\hline 38. Najdłuższy dzień & $\begin{array}{l}\text { Darryl F. Zanuck; Bernhard } \\
\text { Wicki; Gerd Oswald ; Ken } \\
\text { Annakin; Andrew Marton }\end{array}$ & USA/1962 & Dramat wojenny \\
\hline 39. Co się zdarzyło Baby Jane & Robert Aldrich & USA/1962 & Dramat/thriller \\
\hline 40. Kleopatra & Joseph L. Maniewicz & USA/1963 & Biograficzny/historyczny \\
\hline 41. Lampart & Luchino Visconti & Francja/Włochy/1963 & Kostiumowy/ romans \\
\hline 42. Wojna i pokój & Sergey Bondarchuk & ZSRR/1965 & Dramat historyczny \\
\hline 43. Jezus z Montrealu & Denys Arcand & Francja/Kanada/1989 & Dramat \\
\hline \multicolumn{4}{|l|}{ CD 7.} \\
\hline $\begin{array}{l}\text { 44. Goście wieczerzy } \\
\text { pańskiej }\end{array}$ & Ingmar Bergman & Szwecja/1963 & Dramat \\
\hline 45. Dziecko wojny & Andriej Tarkowski & ZSRR/1962 & Dramat wojenny \\
\hline 46. Doktor Żywago & David Lean & USA/1965 & Melodramat \\
\hline 47. Alphaville & Jean-Luc Godard & Francja/1965 & Film noir/ sci-fi \\
\hline 48. Sklep przy głównej ulicy & Jan Kadar & Czechosłowacja/1965 & Dramat wojenny \\
\hline 49. Oto jest głowa zdrajcy & Fried Zinnemann & Wielka Brytania/1966 & Biograficzny/kostiumowy \\
\hline
\end{tabular}




\begin{tabular}{|c|c|c|c|}
\hline Tytuł Filmu & Reżyser & $\begin{array}{l}\text { Kraj pochodzenia } \\
\text { i rok produkcji }\end{array}$ & Gatunek \\
\hline $\begin{array}{l}\text { 50. Niepokoje wychowanka } \\
\text { Torlessa }\end{array}$ & Volker Schlondorff & Francja/RFN/1966 & Thriller \\
\hline \multicolumn{4}{|l|}{ CD 8.} \\
\hline 51. 0 uroczystości i gościach & Jan Nemec & Czechosłowacja/1966 & Komedia obyczajowa \\
\hline 52. Z & Costa Gavras & Francja/1969 & Thriller \\
\hline 53. Matnia & Roman Polański & Wielka Brytania/1966 & Dramat \\
\hline $\begin{array}{l}\text { 54. Legenda o świętym } \\
\text { pijaku }\end{array}$ & Ermanno Olmi & Francja/1988 & Dramat psychologiczny \\
\hline 55. Piłat i inni & Andrzej Wajda & Polska/RFN/1972 & Dramat \\
\hline 56. Wniebowstąpienie & Łarisa Szepitko & ZSRR/1977 & Dramat wojenny \\
\hline 57. Płonący wieżowiec & John Guillermin & USA/1974 & Katastroficzny \\
\hline \multicolumn{4}{|l|}{ CD 9.} \\
\hline $\begin{array}{l}\text { 58. Samotność } \\
\text { długodystansowca }\end{array}$ & Tony Richardson & Wielka Brytania/1962 & Dramat obyczajowy \\
\hline 59. Lawrence z Arabii & David Lean & USA/1962 & Dramat \\
\hline 60. Andriej Rublow & Andriej Tarkowski & ZSRR/1966 & Biograficzny \\
\hline 61. Grek Zorba & Mihalis Kakogiannis & Grecja/1964 & Dramat \\
\hline 62. Odyseja kosmiczna 2001 & Stanley Kubrick & USA/1968 & Sci-fi \\
\hline 63. Zmierzch bogów & Luchino Visconti & Włochy/1969 & Dramat wojenny \\
\hline \multicolumn{4}{|l|}{ CD 10.} \\
\hline 64. Pięć łatwych utworów & Bob Rafelson & USA/1970 & Dramat obyczajowy \\
\hline 65. Brudny Harry & Don Siegel & USA/1971 & Krymianł \\
\hline 66. Ojciec Chrzestny & Francis Ford Coppola & USA/1972 & Gangsterski \\
\hline 67. Kabaret & Bob Fosse & USA/1972 & Dramat/musical \\
\hline 68. Szczęśliwy człowiek & Lindsay Anderson & USA/1973 & Obyczajowy/satyra \\
\hline 69. Aguirre - gniew boży & Werner Herzog & RFN/1972 & Biograficzny \\
\hline \multicolumn{4}{|l|}{ CD 11.} \\
\hline $\begin{array}{l}\text { 70. Zagadka Kaspara } \\
\text { Hausera }\end{array}$ & Werner Herzog & RFN/1974 & Biograficzny/historyczny \\
\hline 71. Piknik pod wiszącą skałą & Peter Weir & Australia/1975 & Dramat \\
\hline $\begin{array}{l}\text { 72. Lot nad kukułczym } \\
\text { gniazdem }\end{array}$ & Milos Forman & USA/1975 & Dramat psychologiczny \\
\hline 73. Taksówkarz & Martin Scorsese & USA/1976 & Dramat \\
\hline 74. Czas apokalipsy & Francis Ford Copola & USA/1979 & Dramat wojenny \\
\hline 75. Stalker & Andriej Tarkowski & ZSRR/1979 & Sci-fi \\
\hline
\end{tabular}

Źródło: Opracowanie własne

\section{WYKAZ SKRÓTÓW:}

PBC - Polska Biblioteka Cyfrowa,

PDL - Polish Digital Library

PSRW - Polska Sekcja Radia Watykańskiego 


\section{Biogram}

Anita Zawisza - doktorantka i wykładowczyni na Wydziale Dziennikarstwa, Informacji i Bibliologii, dyscyplina nauki o mediach i komunikacji społecznej. Autorka publikacji odnoszących się do wybranych aspektów, problemów badawczych dot. polskiej kinematografii. Zainteresowania badawcze skupiają się wokół analizy wizerunku postaci filmowych (w szczególności duchownych Kościoła katolickiego).

ORCID: 0000-0001-7050-5889 